\title{
Rozdzielczość danych sejsmicznych w świetle możliwości modyfikacji domeny spektralnej pola falowego oraz wariantowości schematu i parametrów akwizycji na podstawie analizy danych syntetycznych
}

\begin{abstract}
W artykule przedstawiono dwa różne podejścia do zagadnienia zwiększania rozdzielczości danych sejsmicznych. Pierwsze, omówione szczegółowo w artykule pt.: Dobór optymalnej rozdzielczości sekcji sejsmicznej na drodze analizy i modyfikacji charakterystyk spektralnych danych sejsmiki powierzchniowej i otworowej, pokazuje możliwości poszerzenia charakterystyki spektralnej pola falowego na drodze modyfikacji zapisu sejsmicznego z wykorzystaniem danych otworowych, natomiast drugie wykorzystuje możliwości manipulacji i doboru parametrów akwizycji, a szczególnie parametrów (krotności) sumowania.

Słowa kluczowe: akwizycja danych sejsmicznych, rozdzielczość, operator modyfikacji spektralnej, krotność sumowania.

\section{Resolution of seismic data in the view of possibility of wave field spectral domain modification and seismic acquisition parameters based on the analysis of synthetic data}

In the paper two different approaches to the issue of seismic resolution enhancement are presented. The first approach is discussed in detail in the paper: The choice of optimal resolution of seismic data for given geological objects through the application of borehole velocity measurement for spectral modification - where the possibility of broadening of wave field spectral characterization via modification of seismic data with the use of well log was presented. The second approach, utilizes the possibility of tuning of acquisition parameters, especially fold-coverage stacking parameters.
\end{abstract}

Key words: seismic data acquisition, resolution, spectral modification operator, fold-coverage stacking parameter.

\section{Wprowadzenie}

Analizując wyniki interpretacji geologicznej pomiarów, praktycznie każdej dowolnej metody geofizycznej, nie sposób nie zwrócić uwagi na powtarzający się standardowy trójpodział sekwencji działań prowadzących do uzyskania wyniku (o różnym stopniu realności odtworzenia budowy badanego obiektu) stanowiącego przedmiot podjętego projektu badawczego.

Wspomniany trójpodział, będący treścią schematu postępowania (ang. workflow), to:

- zbiory danych wejściowych (DATA) i ich ewentualna korekcja,

- zbiory procedur przetwarzania i zintegrowanej interpretacji wyników uzyskanych i przedstawionych do rozwiązania danego problemu danych,
- zbiory propozycji aplikacji praktycznych, możliwych do realizacji na podstawie w określony sposób skonfigurowanego zbioru danych.

Waga danych wejściowych jest niepodważalna i decyduje o poprawności uzyskiwanych wyników. Pośród wielu metod geofizycznych metoda sejsmiczna jest tą, która pozwala na przestrzenny, trójwymiarowy ogląd ośrodka geologicznego. Jednak z drugiej strony wymaga pewnego rodzaju potwierdzenia wynikami pomiarów (najczęściej profilowania w otworach lub w laboratoriach na próbach skał wydobytych z otworów), które podają bezpośrednio wartości szukanych parametrów.

Metoda sejsmiczna, szczególnie w opcji przestrzennej 3D, wielokomponentowej 3C lub też dynamicznej 4D, gdzie prowadzi 
się badania zgodnie z upływającym czasem, jest techniką generującą wysokie koszty realizacji. Oczywistym jest więc, że uzyskanie rejestracji wysokiej jakości jest bardzo ważne, ponieważ utraty jakości danych nie da się zrekompensować nawet bardzo skomplikowanym działaniem w ramach przetwarzania. Jakość danych sejsmicznych jest oceniana wielostopniowo: od oceny magnitudy amplitudy refleksów oraz stosunku sygnału do zakłóceń. Współczesne bardzo wysokie wymagania dotyczące jakości danych sejsmicznych wyrażane są poprzez wysoką rozdzielczość, czyli pośrednio poprzez szeroki zakres częstotliwości obecnych w zapisie pola sejsmicznego.

Wymaganie wysokiej rozdzielczości wyniknęło z potrzeb generowanych przez charakterystykę złóż niekonwencjonalnych, a szczególnie złóż gazu w formacjach łupkowych, gdzie zarówno warstwa zbiornikowa, jak i skała płonna są „obiektami" o bardzo małej miąższości. Zatem odtworzenie budowy takiego ośrodka jest trudne i wymaga sejsmiki wysokiej rozdzielczości (Broad Band Seismic). Jednocześnie wiadomo, że rozdzielczość danych sejsmicznych zasadniczo zależy od sposobu prowadzenia prac polowych, a więc od schematu i parametrów akwizycji, silnie decydujących o wynikach sumowania zgodnie z procedurą Wspólnego Punktu Odbicia i od doboru krotności sumowania mającego wpływ na stosunek sygnału do zakłócenia (S/N - Signal to Noise Relation).
W cyklu artykułów przedstawionych przez autorkę w wyniku realizacji jednego z zadań programu Polski Gaz Łupkowy, projekt GASŁUPSEJSM, poświęconych rozdzielczości (zadanie 2 pt.: Poszukiwanie, rozpoznawanie - modelowanie i przetwarzanie danych sejsmicznych, $w$ tym metodyka określania żądanej rozdzielczości sejsmicznego pola falowego w procesie lokalizacji, udostepniania i eksploatacji formacji tupkowych), analizowano możliwości opracowanego autorskiego sposobu modyfikacji spektralnej sejsmicznego pola falowego, ukierunkowanego na wybrane, wskazane obiekty złożowe. Przedstawiono wyniki charakteryzujące reguły reakcji zespolonego spektrum amplitudowego i fazowego na złożoność budowy geologicznej.

Przy okazji zauważono zależność charakterystyki spektralnej sejsmicznego pola falowego oraz parametrów akwizycji i krotności sumowania. Zaobserwowane prawidłowości sprawdzono na danych teoretycznych, utworzonych dla modelu będącego wynikiem interpretacji jednego z obiektów, opracowywanych w ramach wyżej wymienionego programu badawczego.

Na rysunku 1 przedstawiono sekwencję tworzenia modelu prędkościowo-głębokościowego dla obiektu SK_W1 (Polska północno-wschodnia).

Danymi wejściowymi była transformowana z domeny głębokości wersja czasowa danych profilowania prędkości Vpp

\section{Wersja głębokościowa}

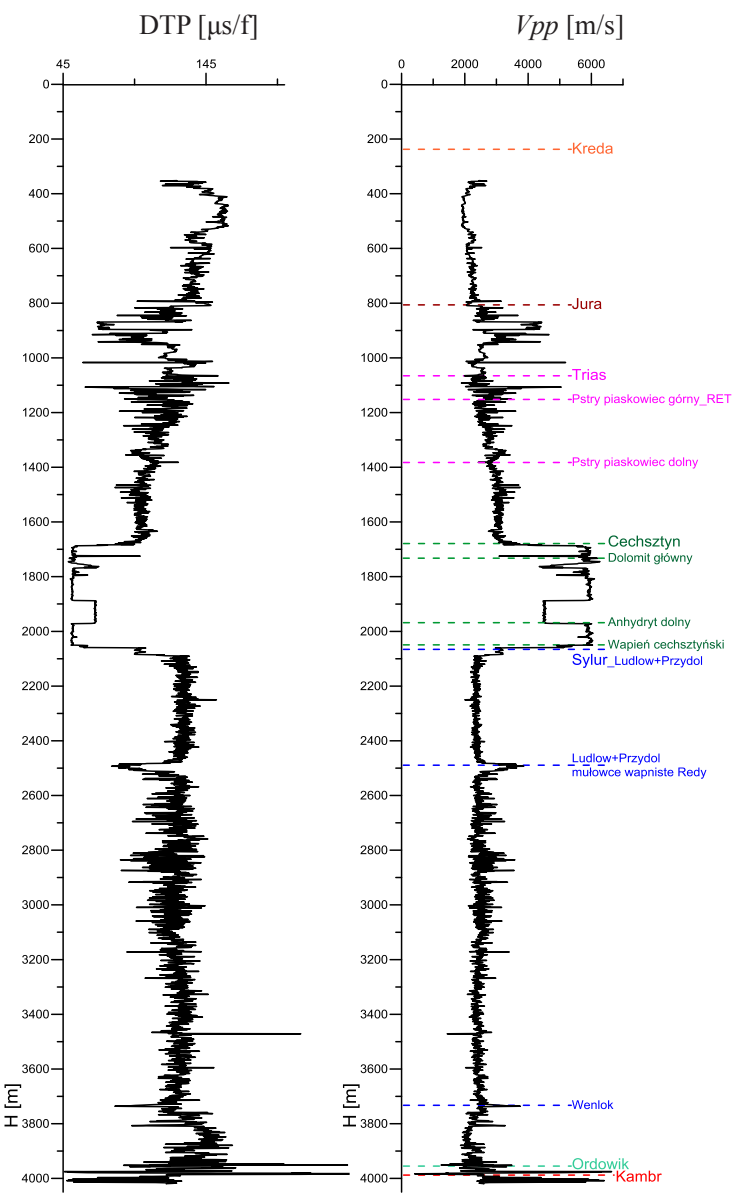

Wersja czasowa
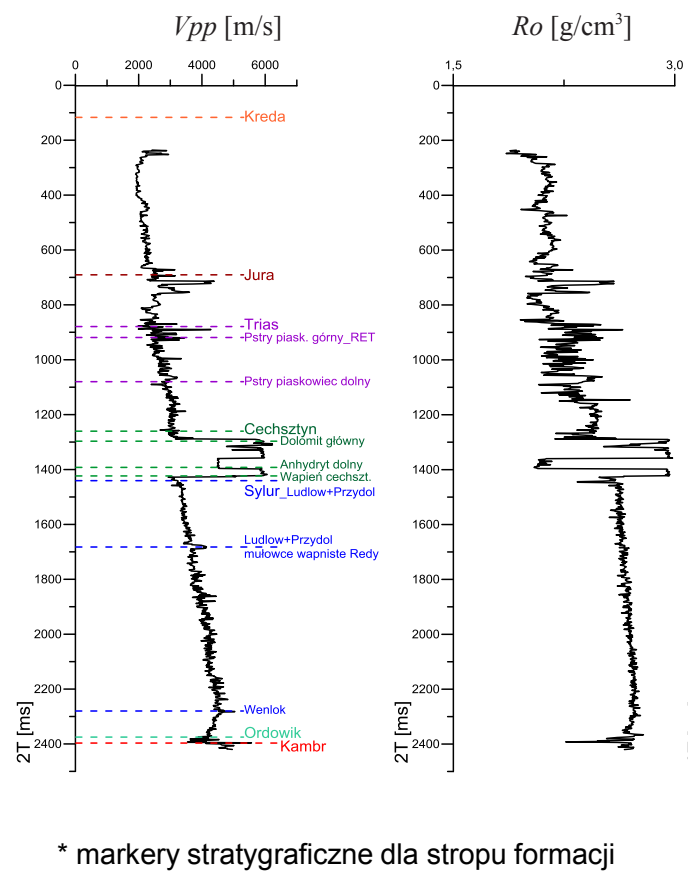

* markery stratygraficzne dla stropu formacji

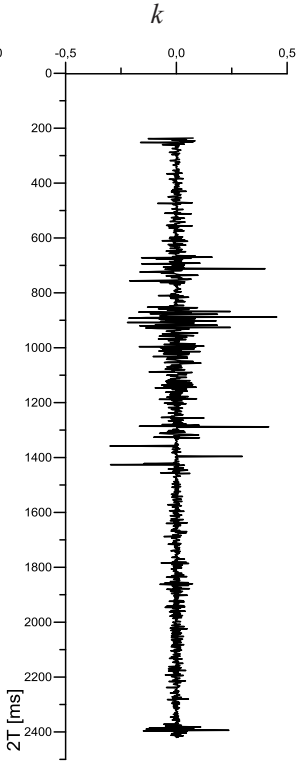

Rys. 1. Wyniki profilowania akustycznego i gęstości w otworze SK_W1 transformowane do domeny czasowej 
i gęstości $\rho$ w otworze oraz obliczona krzywa refleksyjności $k$ normalizowana w zakresie $[-1,+1]$. Ponadto wykorzystano jedną z sekcji czasowych projektu sejsmiki 3D (SK_IL140), charakteryzującą się prawie równoległym ułożeniem warstw (rysunek 2a). Dla sekcji tej przeprowadzono inwersję sejsmiczną w aspekcie impedancji akustycznej oraz prędkości (rysunek 2b, c).

Aplikacja tej procedury, po transformacji wyników do domeny głębokościowej (rysunek 3), dała podstawę przedstawienia przybliżonego i dokładnego modelu prędkościowo-głębokościowego (rysunek 3a, b).

Sprawdzenie modelu (rysunek 4) poprzez przedstawienie sekcji czasowej w wersji NORMAL INCIDENCE $w$ porównaniu $z$ wynikami profilowania akustycznego pozwala na akceptację modelu jako danych, do których możemy odnosić uzyskiwane w dalszym postępowaniu fakty i obliczenia, a których celem było zaobserwowanie wzajemnej zależno-

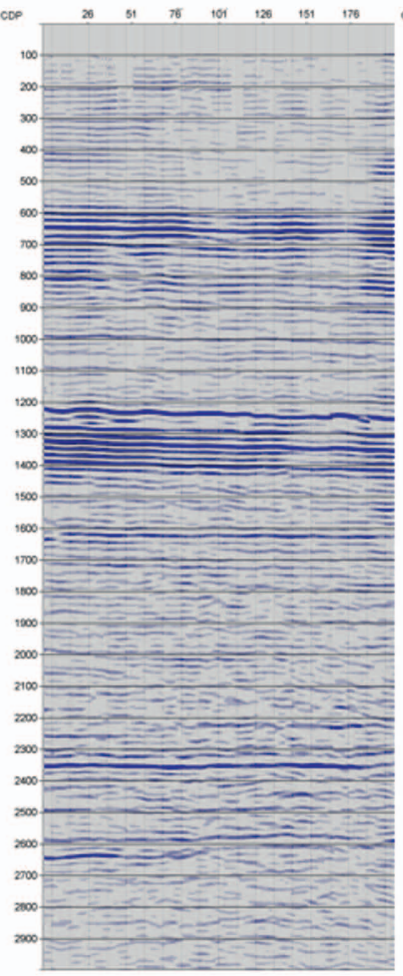

b)

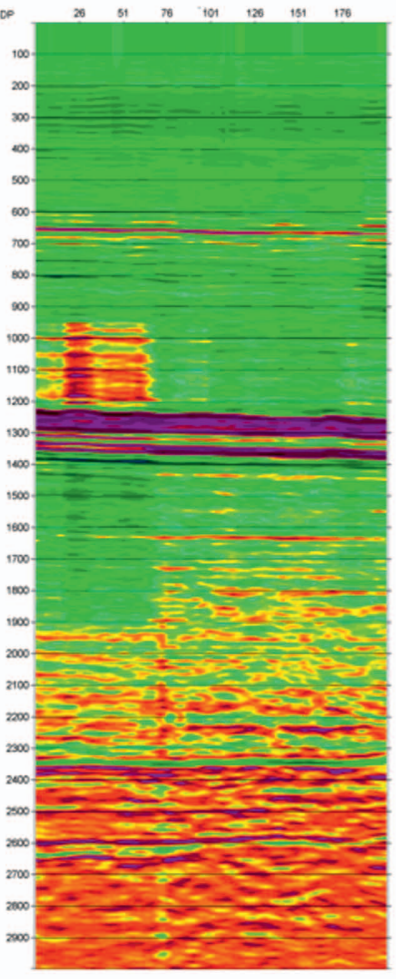

d)

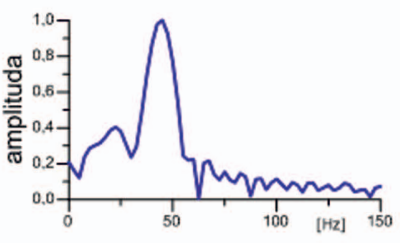

c)

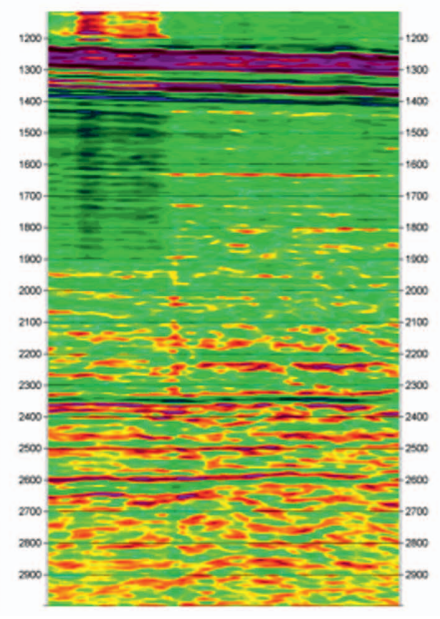

Rys. 2. Tworzenie modelu prędkościowo-głębokościowego dla obiektu W1 na podstawie interpretacji i inwersji sejsmicznej. Profil SK_IL140: a) sekcja sejsmiczna wejściowa,

b) sekcja impedancji akustycznej, c) sekcja prędkości akustycznej fali podłużnej, d) widmo amplitudowe obliczone dla sekcji wejściowej
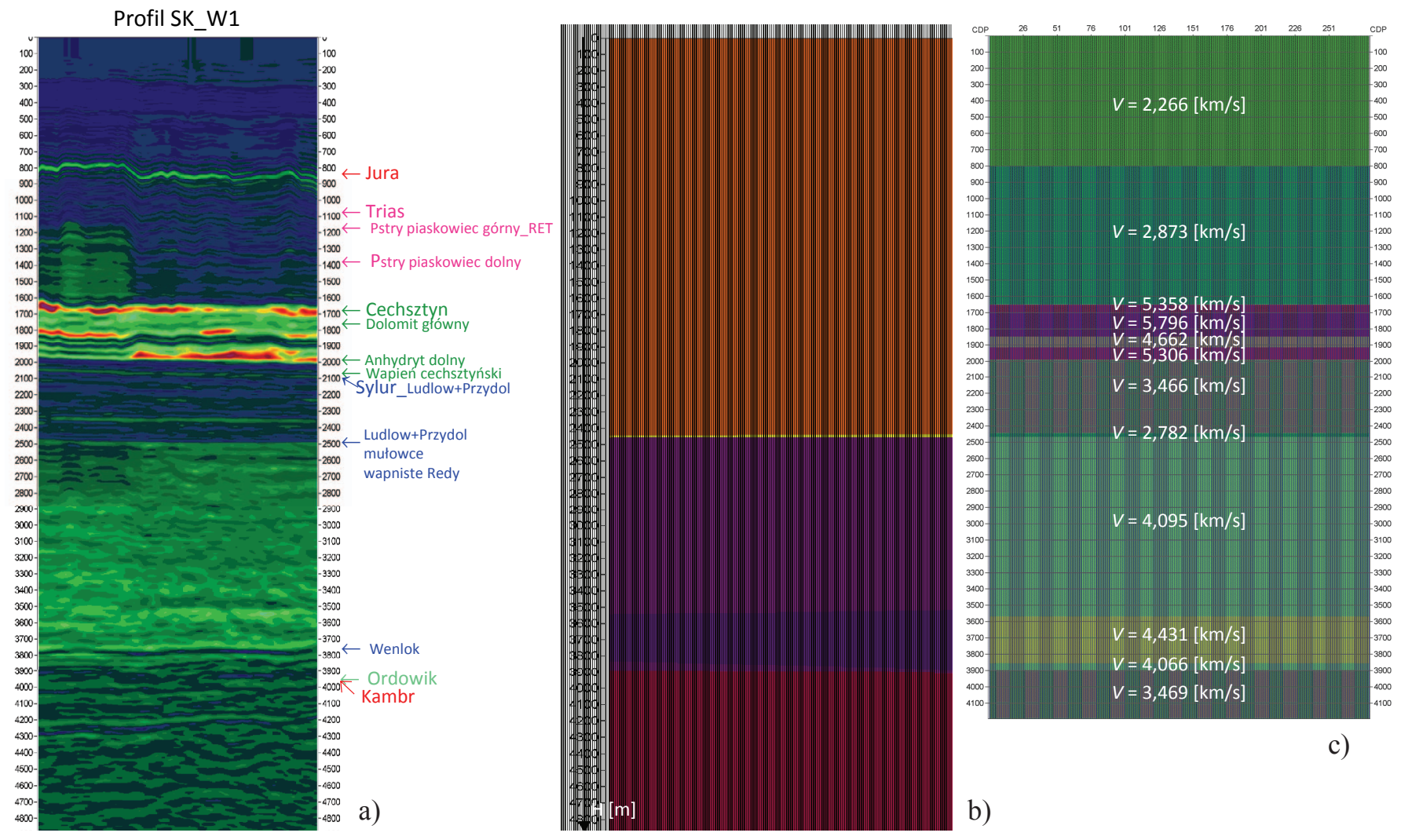

c)

b)

Rys. 3. Pole prędkości w domenie głębokości (profil SK_W1) (a) i odtworzone modele prędkościowo-głębokościowe (b), (c) 


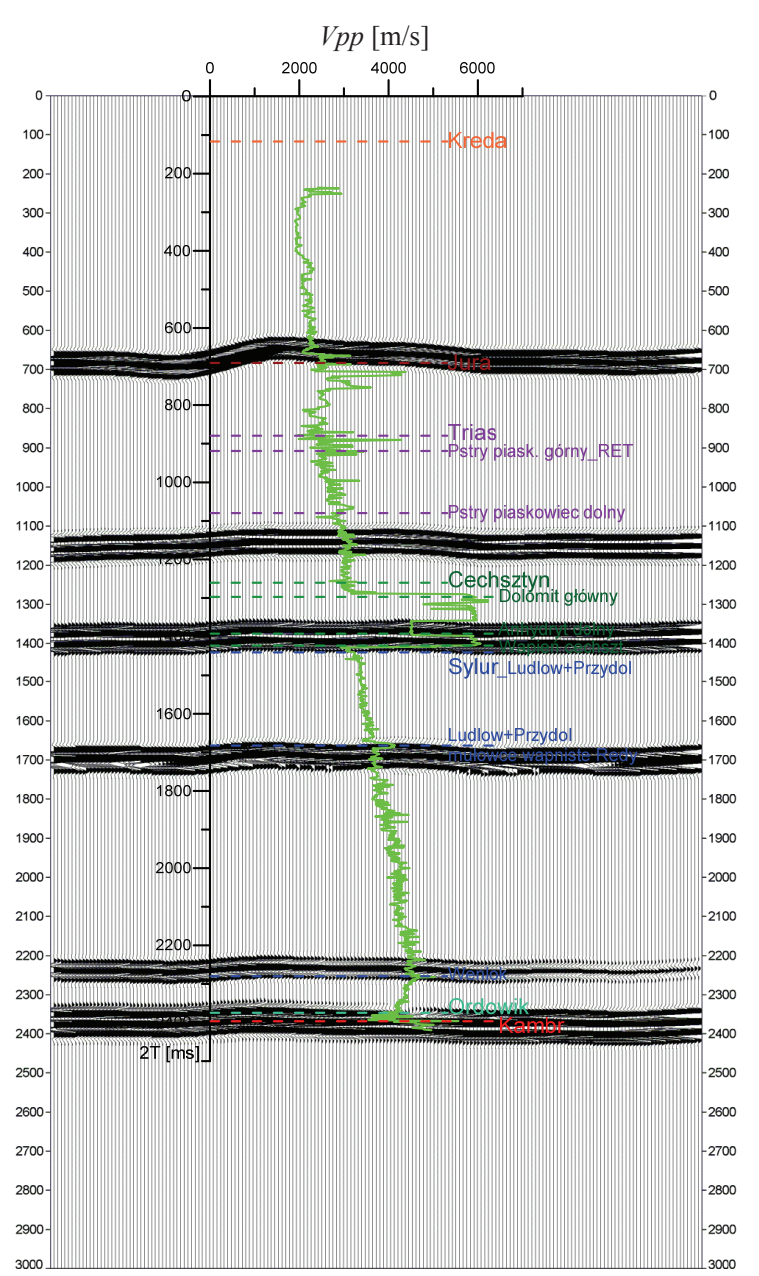

Rys. 4. Sekcja teoretyczna modelowana dla przybliżonego modelu przedstawionego na rysunku $3 \mathrm{c}$

Modelowanie sejsmiczne rozpoczęto od określenia stopnia dopasowania modelu do danych rzeczywistych, drogą oceny pozycji horyzontów na sekcji T0 $\mathrm{w}$ relacji z danymi profilowania prędkości (rysunek 4) oraz generowania rekordów pojedynczych, dla których zaaplikowano sygnały elementarne o zróżnicowanych częstotliwościach (20, 40, $80 \mathrm{~Hz})$.

Przyjęty do modelowania obiekt płaskorównoległy (układ 12 warstw) oraz rozkład prędkości przedstawiono na rysunku 5 i w odpowiadającej mu tablicy 1. Obliczenia prowadzono zgodnie ze schematem akwizycji zaprezentowanym na wspomnianym rysunku 5 .

Parametry schematu akwizycji:

- rozstaw środkowy (20 PW),

- offset max: $7000 \mathrm{~m}$,

- odległość między punktami wzbudzenia $=100 \mathrm{~m}$,

- odległość między punktami odbioru $=100 \mathrm{~m}$,

- odległość między punktami $\mathrm{WPG}=50 \mathrm{~m}$.

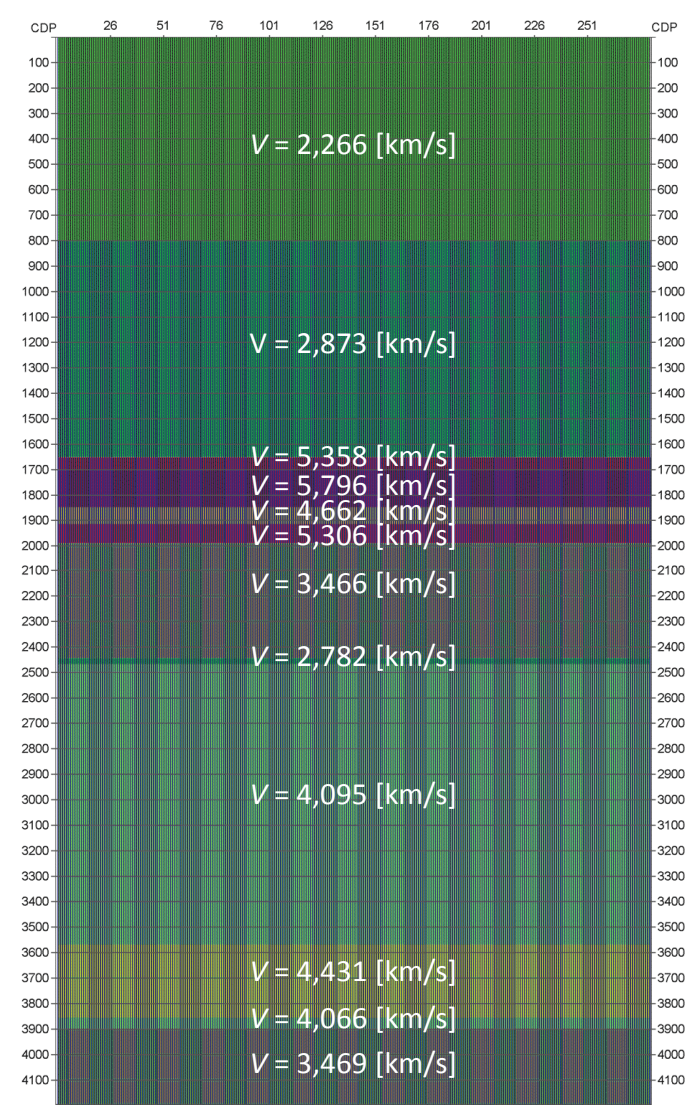

Rys. 5. Model prędkości średnich charakteryzujący płaskorównoległy układ warstw na przestrzeni przyjętego obiektu i założonego schematu obliczeń

Tablica 1 . Numeryczny opis modelu przyjętego do obliczeń

\begin{tabular}{|c|c|c|c|c|c|}
\hline \multicolumn{5}{|c|}{$-7,0100$} & \multicolumn{5}{c|}{$X[\mathrm{~km}]$} & \multicolumn{2}{c|}{7,0100} \\
\hline$H[\mathrm{~km}]$ & $V[\mathrm{~km} / \mathrm{s}]$ & $H[\mathrm{~km}]$ & $V[\mathrm{~km} / \mathrm{s}]$ & $H[\mathrm{~km}]$ & $V[\mathrm{~km} / \mathrm{s}]$ \\
\hline 0,8400 & 2,266 & 0,8040 & 2,266 & 0,8040 & 2,266 \\
\hline 1,6520 & 2,873 & 1,6520 & 2,873 & 1,6520 & 2,873 \\
\hline 1,7040 & 5,358 & 1,7040 & 5,358 & 1,7040 & 5,358 \\
\hline 1,8480 & 5,796 & 1,8480 & 5,796 & 1,8480 & 5,796 \\
\hline 1,9160 & 4,662 & 1,9160 & 4,662 & 1,9160 & 4,662 \\
\hline 1,9920 & 5,306 & 1,9920 & 5,306 & 1,9920 & 5,306 \\
\hline 2,4480 & 3,466 & 2,4480 & 3,466 & 2,4480 & 3,466 \\
\hline 2,4680 & 2,782 & 2,4680 & 2,782 & 2,4680 & 2,782 \\
\hline 3,5680 & 4,095 & 3,5680 & 4,095 & 3,5680 & 4,095 \\
\hline 3,8560 & 4,431 & 3,8560 & 4,431 & 3,8560 & 4,431 \\
\hline 3,9000 & 4,066 & 3,9000 & 4,066 & 3,9000 & 4,066 \\
\hline 4,9000 & 3,463 & 4,9000 & 3,463 & 4,9000 & 3,463 \\
\hline
\end{tabular}

\section{Analiza obrazu falowego}

Obliczone hodografy pojedyncze oraz po zaaplikowaniu poprawki NMO pokazano na rysunku $6 \mathrm{a}, \mathrm{b}$. Oceniając wyni- ki w aspekcie wyrównania dynamiki amplitud wzdłuż profilu obserwacji, można zauważyć, że dość wyraźnie zaznacza 
się - właściwie oczywista - zależność częstotliwości przyjętego do modelowania sygnału i charakteru obrazu interferencyjnego na hiperbolach hodografów pojedynczych (odległość punktu odbioru $=100 \mathrm{~m}$; lewa i prawa gałąź hodogra$\mathrm{fu}= \pm 7000 \mathrm{~m}$; całkowita ilość punktów odbioru $=141 \div$ ilość zapisanych tras). Dość istotny wpływ częstotliwości zaznacza się na rekordach po zastosowaniu poprawki dynamicz- nej; daje to wyraźny asumpt do przeprowadzenia analizy pod kątem wpływu częstotliwości obserwowanych na sekcjach na ocenę dynamiki i rozdzielczości rejestrowanych refleksów i horyzontów.

Odpowiadający modelowi (rysunek 5) układ refleksów dobrze odzwierciedla założony rozkład prędkości; wyraźnie obserwuje się to dla sygnału o częstotliwości $40 \mathrm{~Hz}$, co a)

sygnał elementarny $\rightarrow$

$20 \mathrm{~Hz}$

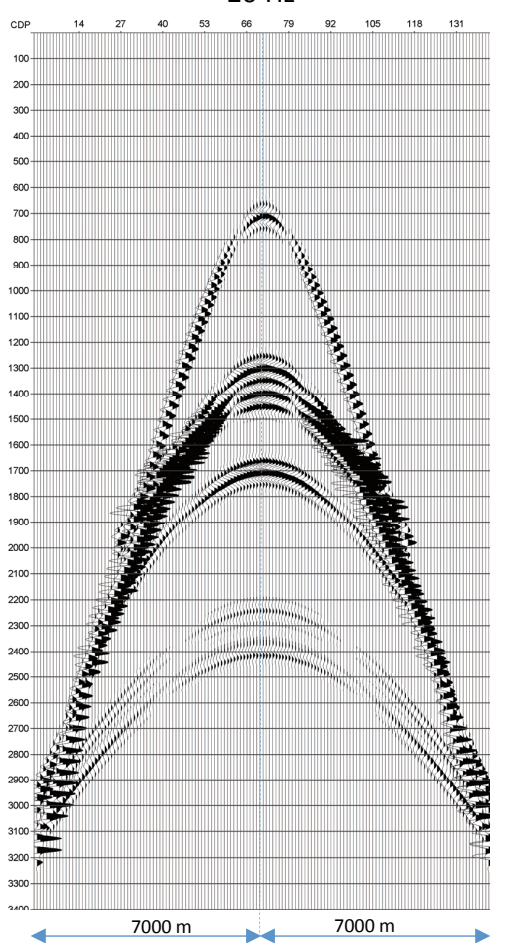

b)
$20 \mathrm{~Hz}$

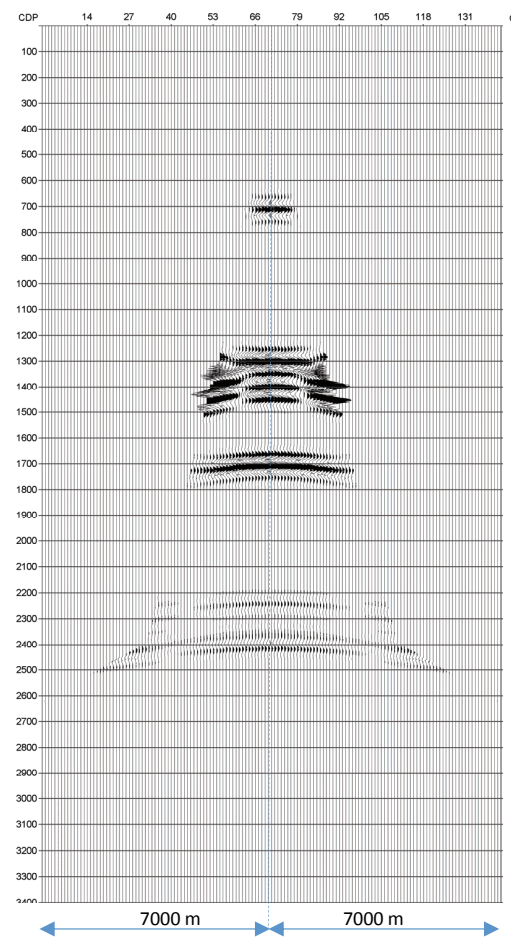

$40 \mathrm{~Hz}$

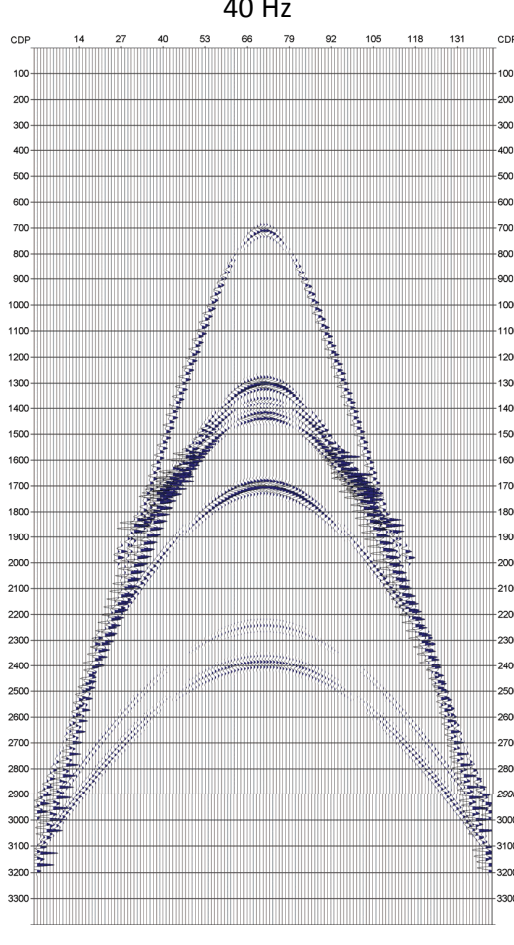

$40 \mathrm{~Hz}$

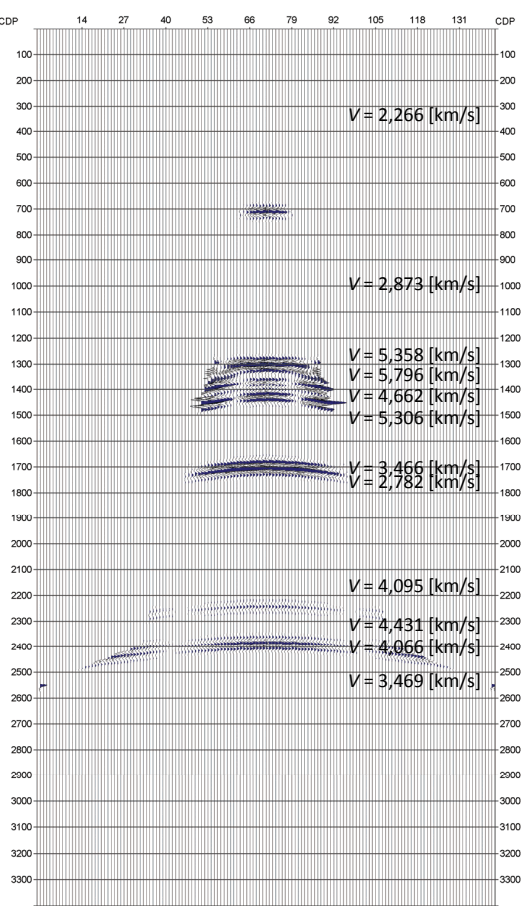

$80 \mathrm{~Hz}$

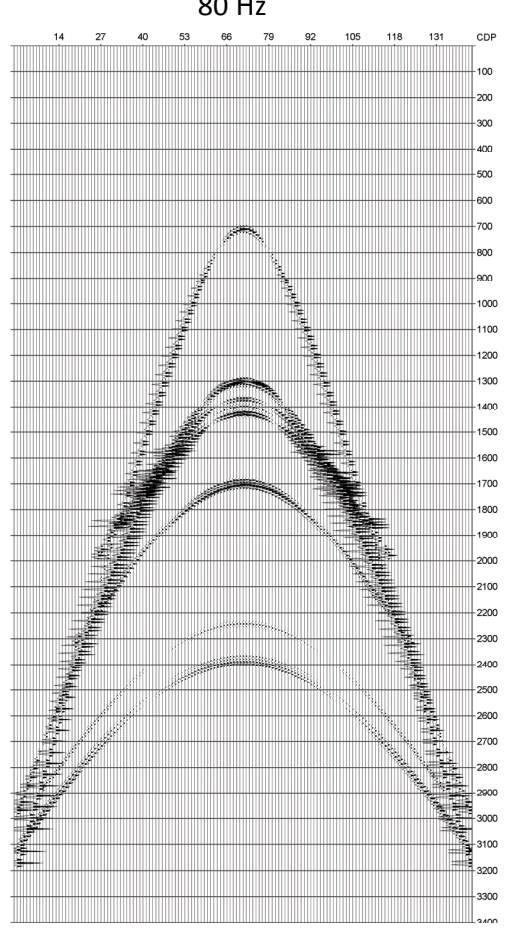

$80 \mathrm{~Hz}$

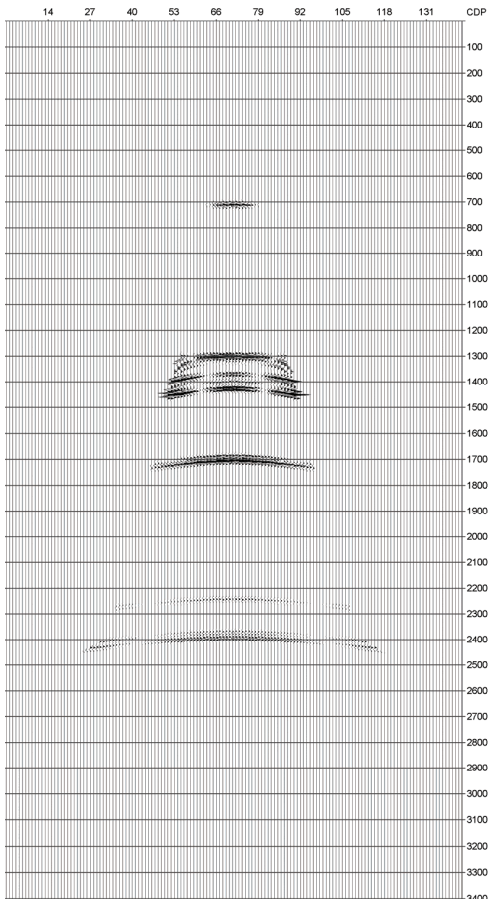


NAFTA-GAZ

c)
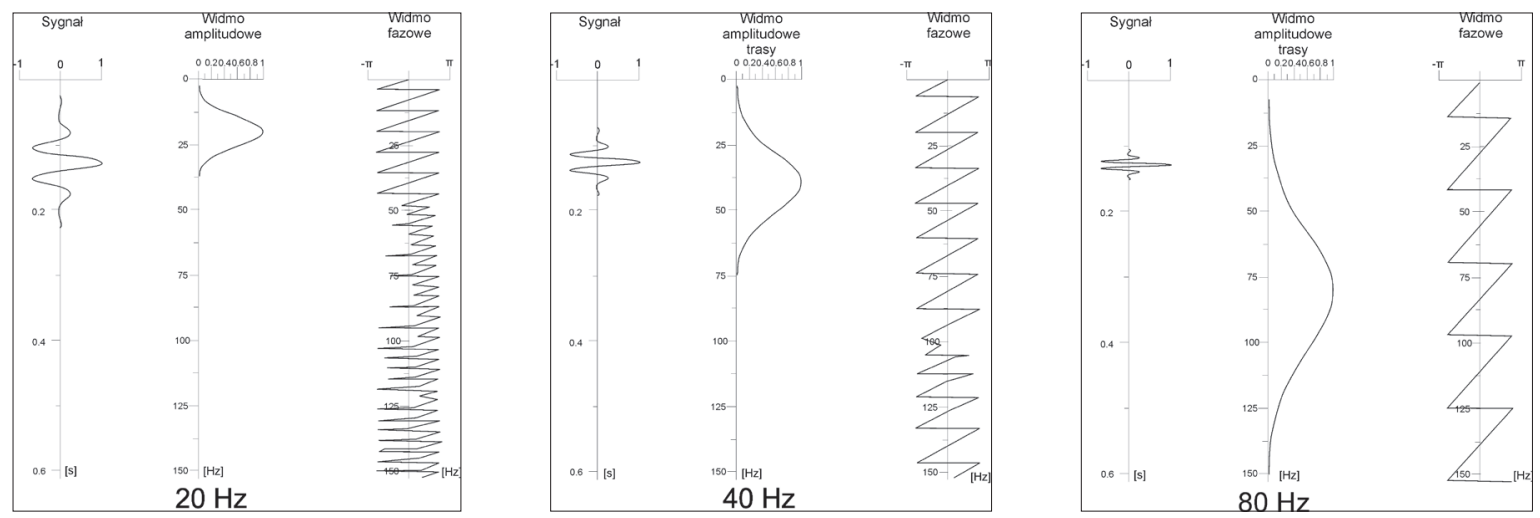

Rys. 6. Teoretyczne rekordy pojedyncze (hodografy) obliczone dla 12-warstwowego modelu geologicznego (a) oraz rekordy pojedyncze po zastosowaniu poprawki NMO (b), sygnały elementarne oraz ich charakterystyki spektralne (c)

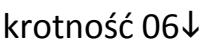
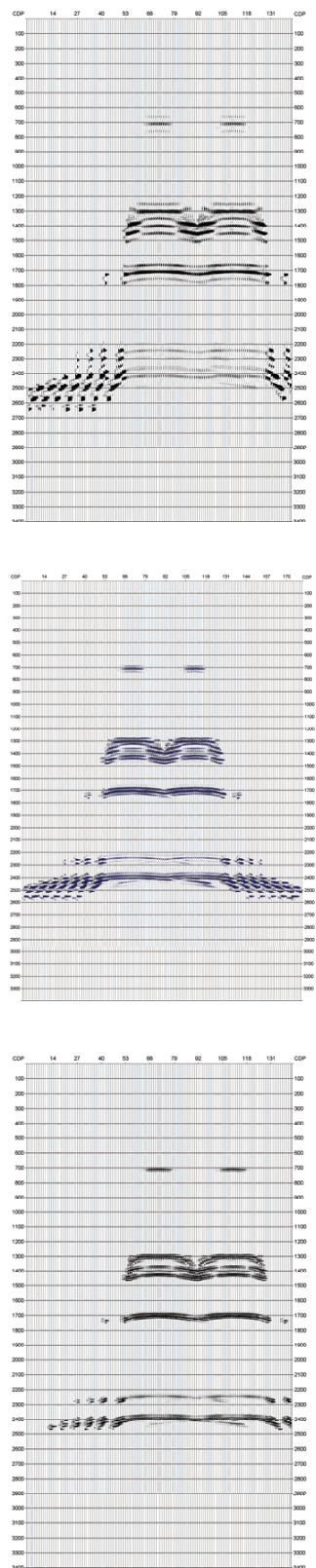

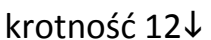
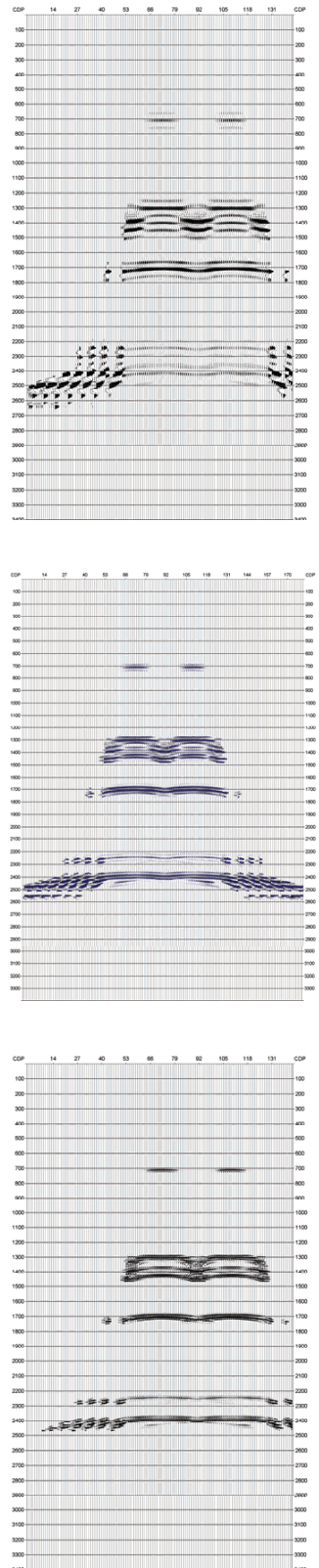

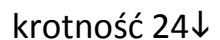

sygnat elementarny $20 \mathrm{~Hz}$

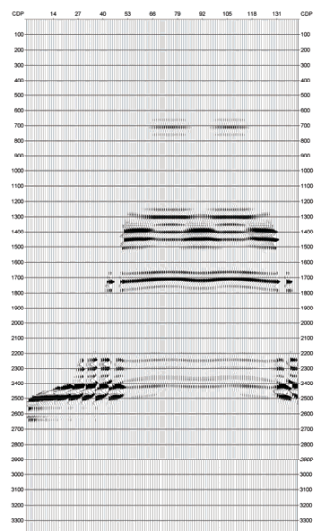

sygnał elementarny $40 \mathrm{~Hz}$

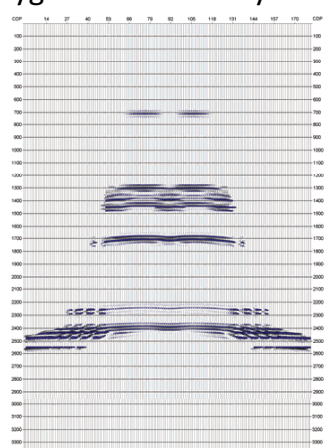

sygnał elementarny $80 \mathrm{~Hz}$

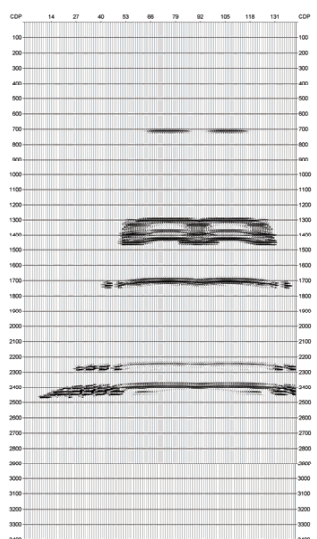

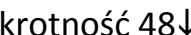

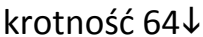
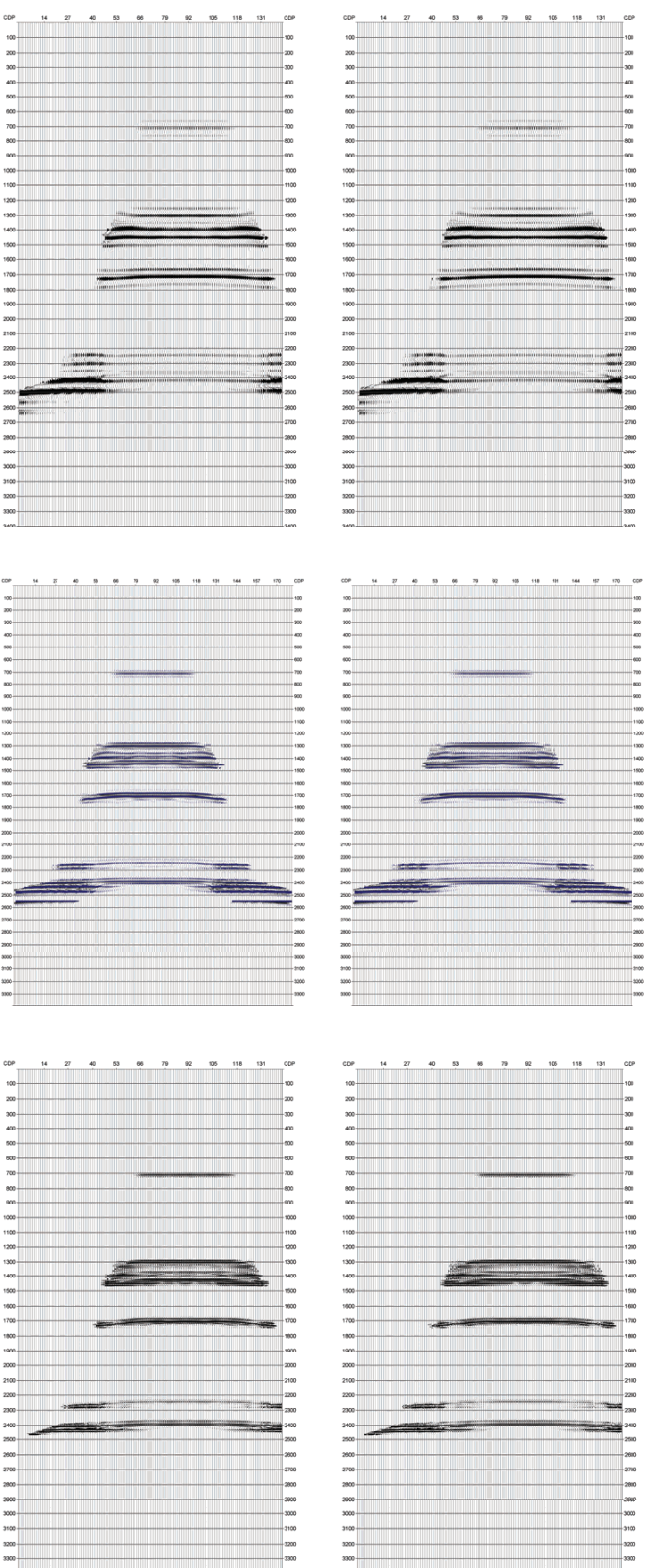

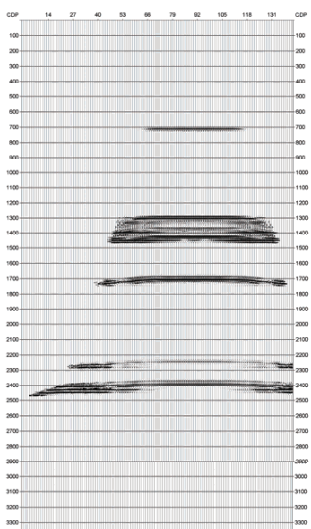

Rys. 7. Analiza rozdzielczości pola falowego w kontekście wyników aplikacji różnej krotności sumowania oraz w kontekście zróżnicowania częstotliwości dominującej sygnału elementarnego (model teoretyczny dla obiektu SK_W1) 
świadczy o poprawnie przetworzonej sekcji wejściowej (rysunek 2). Częstotliwość $80 \mathrm{~Hz}$, wbrew standardowym oczekiwaniom, nie przyniosła najlepszego odtworzenia ośrodka. Dalsze obserwacje dotyczyły oceny wpływu częstotliwości sygnału przyjętego do modelowania na wyrównanie hiperboli hodografu (aplikacja poprawki NMO) oraz na jednoznaczność horyzontów na sekcjach po sumowaniu. Wyniki zastosowania kolejnych wariantów sumowania (krotności) przedstawiono na rysunku 7 (a, b, c, d, e).

Dość szczegółowe analizy relacji częstotliwość - krotność sumowania i rozdzielczość obrazu sejsmicznego ujawniają - intuicyjnie, ale niezbyt precyzyjnie - oczekiwany fakt, że im wyższa krotność sumowania, tym lepsza rozdzielczość geologicznie interpretowanego zapisu. Podobnie jak wiele innych parametrów przetwarzania i ten wyżej analizowany parametr musi być akceptowany pod kątem dostosowania do specyfiki badanego obiektu (ang. target oriented). Ponadto optymalna krotność sumowania wydaje się być różna dla różnych częstotliwości i różnych poziomów sejsmicznych, np. dla sygnału $f=40 \mathrm{~Hz}$ najlepsze odtworzenie ośrodka obserwuje się dla krotności 64 , podczas gdy dla sygnału $f=20 \mathrm{~Hz}$ zwiększenie krotności nie poprawia zauważalnie czytelności horyzontów. Stąd wniosek, że w przypadku danych sej- smicznych o niskiej rozdzielczości (ze względu na charakterystykę spektralną pola falowego) zwiększenie krotności sumowania niekoniecznie pozwala na uzyskanie oczekiwanego lepszego wyniku interpretacyjnego.

Natomiast analiza wyników pozwala na sugestię (rysunek 7), iż wysokorozdzielcze pole falowe, uzyskane na rekordach pojedynczych przed sumowaniem, istotnie eliminuje konieczność stosowania wysokiej krotności sumowania.

Zwraca też uwagę niekorzystny wpływ dużej wielkości "binu" $R$ (długość przedziałów CDP uczestniczących w sumie o danej krotności - rysunek 8). Najkorzystniejsze odtworzenie horyzontów obserwuje się przy wartości $R>1$ (przy analizowanej krotności sumowania 12).

Parametry schematu akwizycji: rozstaw środkowy (20 PW), offset max: 7000 m, odległość między punktami wzbudzenia $=100 \mathrm{~m}$, odległość między punktami odbio$\mathrm{ru}=100 \mathrm{~m}$, odległość między punktami $\mathrm{WPG}=50 \mathrm{~m}$, częstotliwość sygnału elementarnego $=40 \mathrm{~Hz}$.

Dopełnieniem analizy obrazu falowego jest analiza wyników przedstawionych w domenie spektralnej. Na rysunku 9 zaprezentowano zmianę charakterystyki spektralnej wybranych wzdłuż profili tras, sumowanych z krotnością 06 , przy założonej częstotliwości $20 \mathrm{~Hz}$ oraz analogicznie dla krotności 48 i 64.
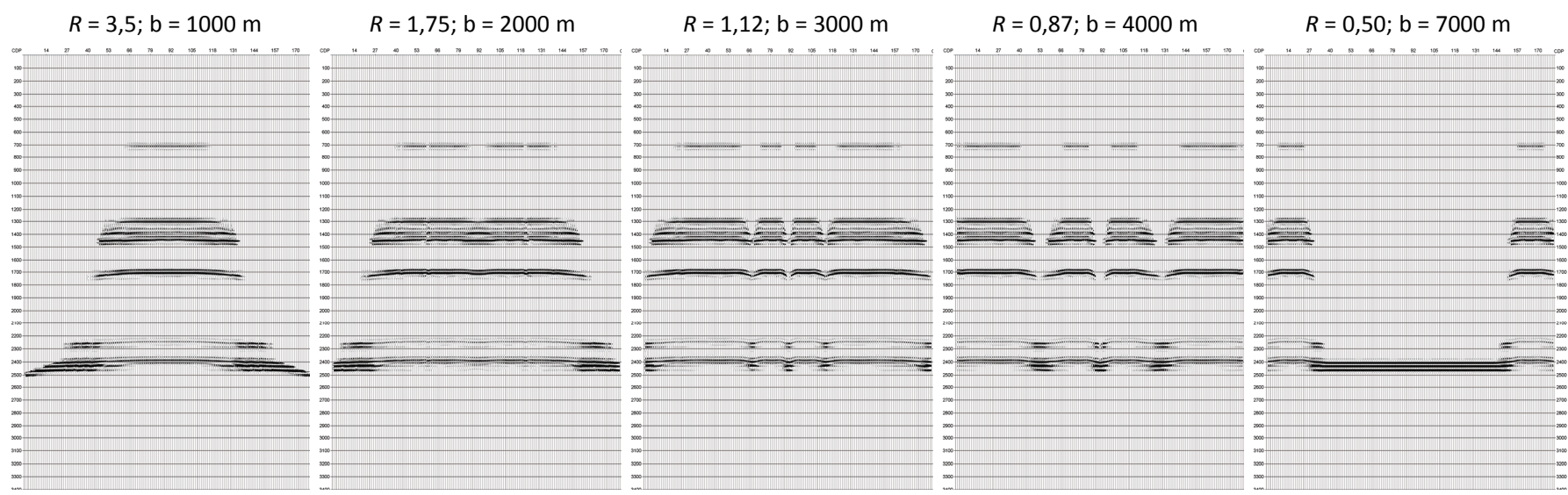

Rys. 8. Analiza wpływu relacji $R$ (długość binu $b$ do długości połowy offsetu) na wyniki sumowania. Model teoretyczny SK_W1

Krotność sumowania 06, sygnał elementarny $20 \mathrm{~Hz}$
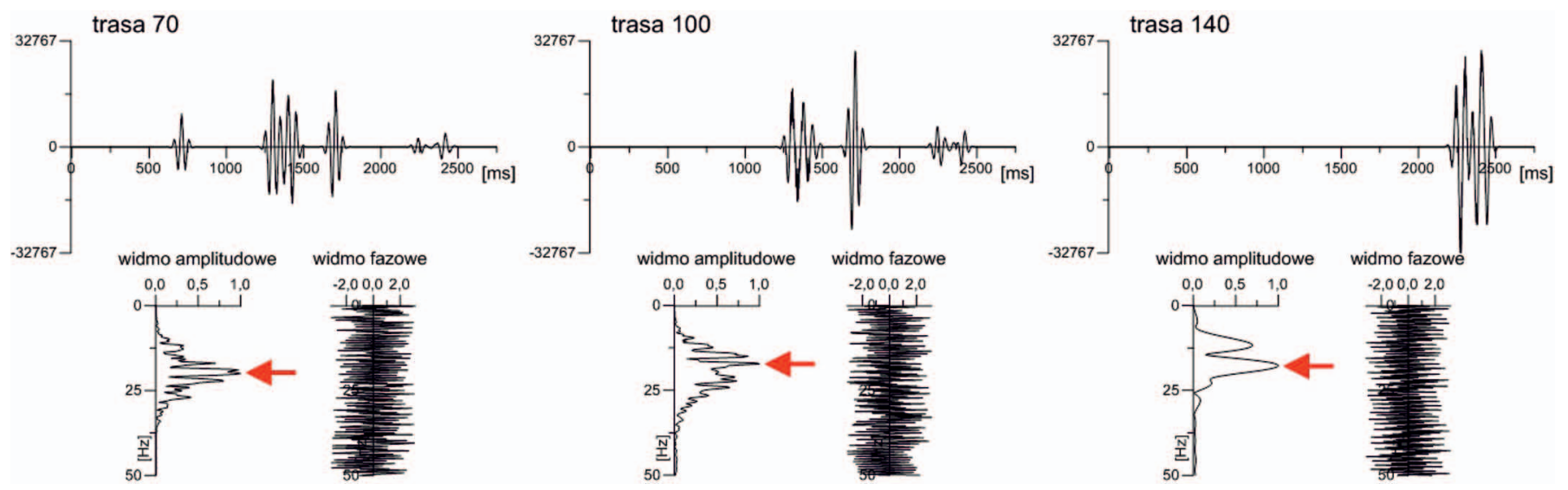

Nafta-Gaz, nr 12/2017 
Krotność sumowania 48, sygnał elementarny $20 \mathrm{~Hz}$
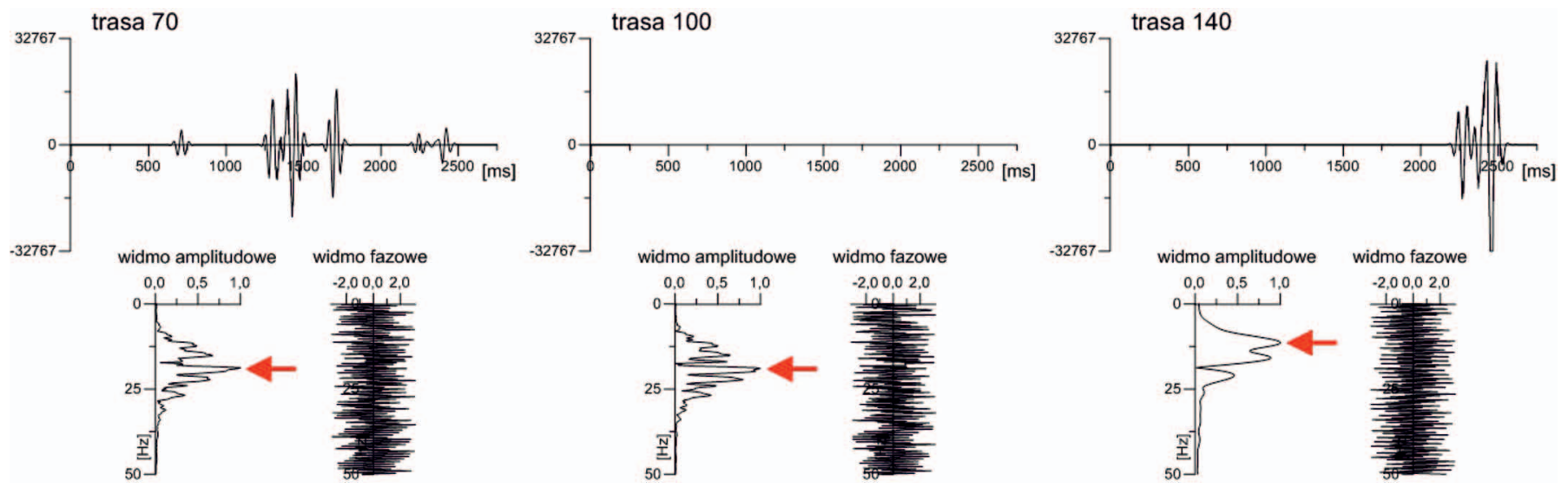

Krotność sumowania 64, sygnał elementarny $20 \mathrm{~Hz}$
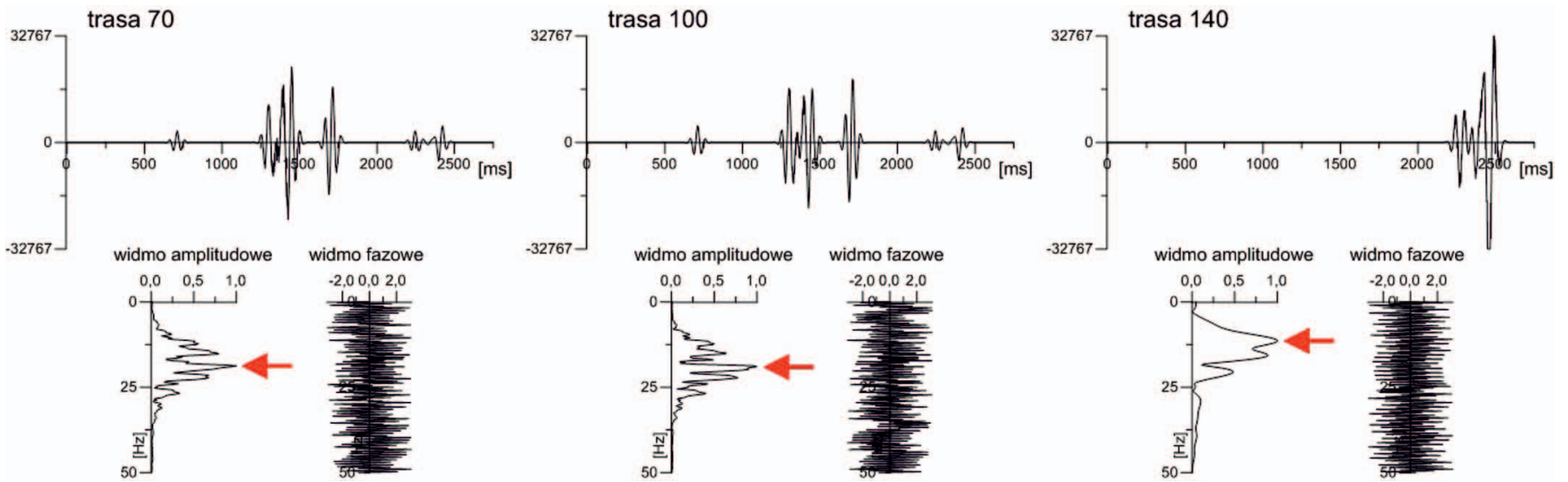

Rys. 9. Analiza zmian charakterystyki spektralnej wybranych wzdłuż profili tras, sumowanych z krotnością 06, 48, 64, przy założonej częstotliwości $20 \mathrm{~Hz}$

Kształt widma silnie związany jest z częstotliwością sygna- odgrywa zauważalnie istotnej roli. Analogiczne obliczenia łu, w przedstawionym przykładzie krotność sumowania nie wykonano dla częstotliwości $80 \mathrm{~Hz}$ (rysunek 10).

Krotność sumowania 06, sygnał elementarny $80 \mathrm{~Hz}$
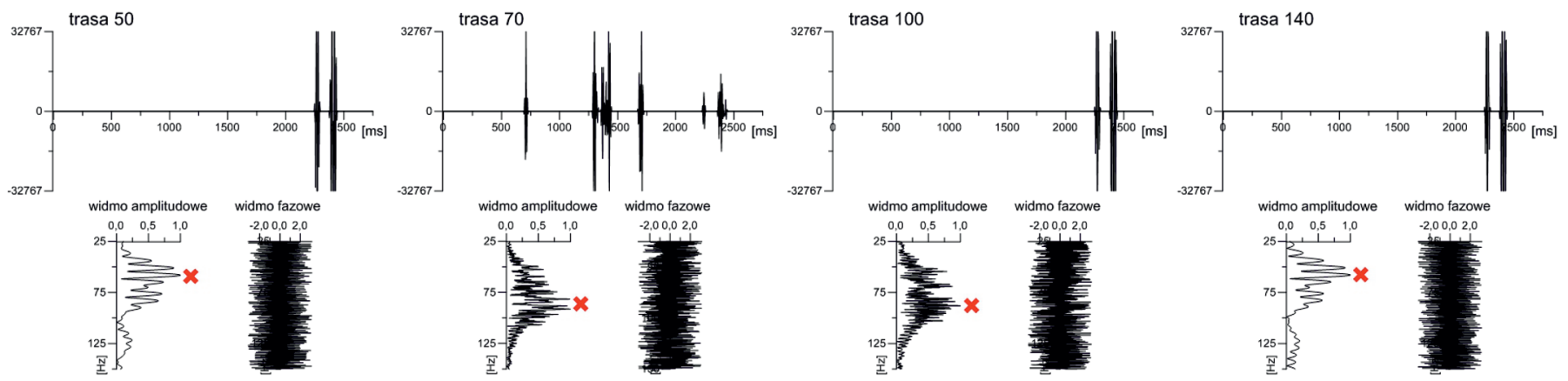

Krotność sumowania 12, sygnał elementarny $80 \mathrm{~Hz}$
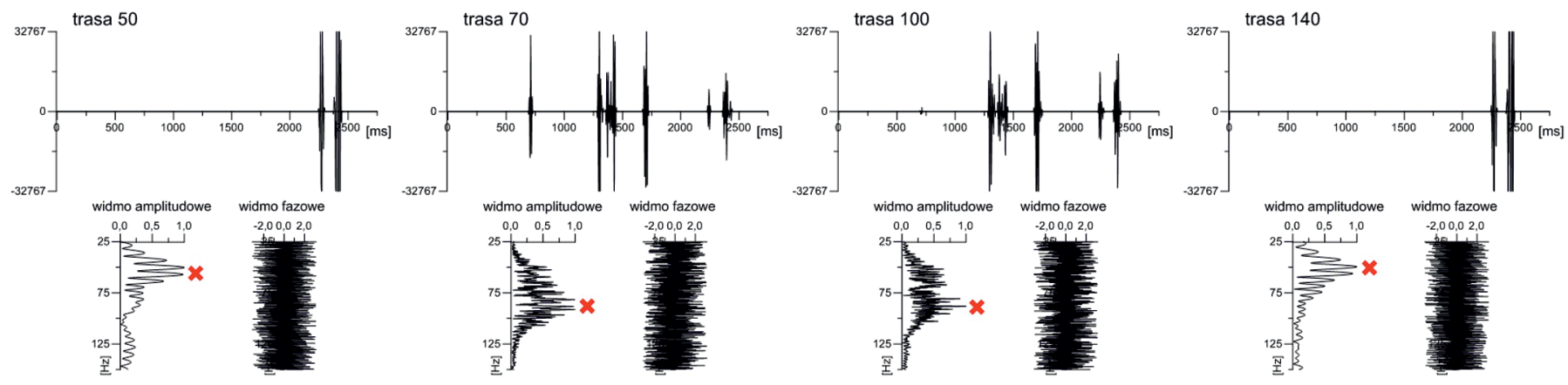
Krotność sumowania 24, sygnał elementarny $80 \mathrm{~Hz}$
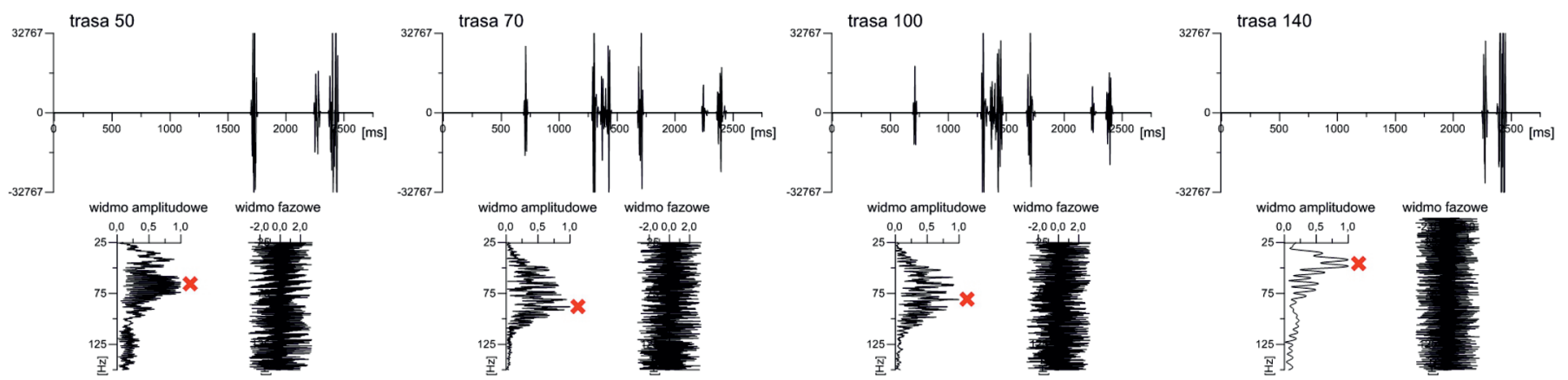

Krotność sumowania 48, sygnał elementarny $80 \mathrm{~Hz}$
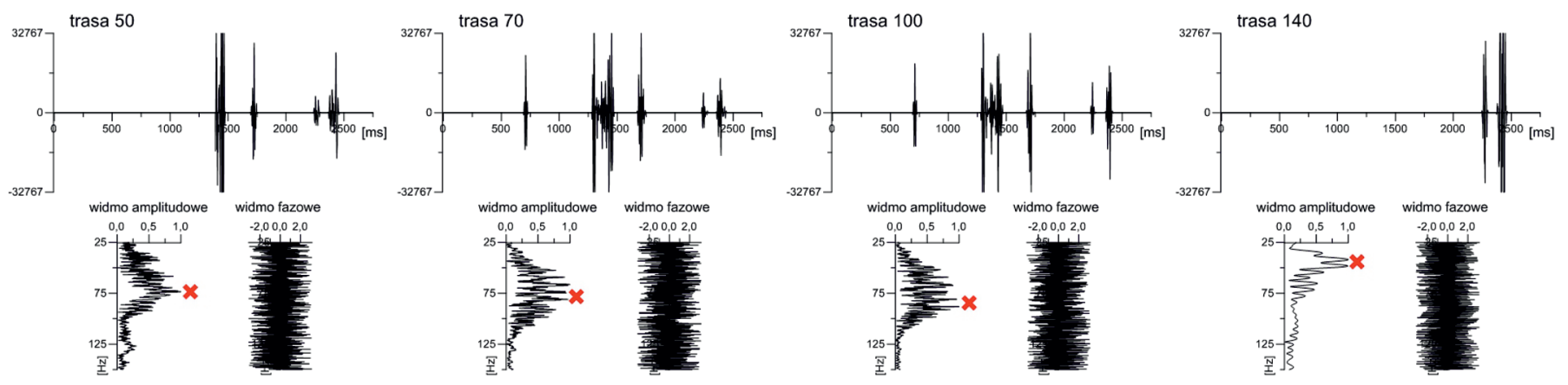

Krotność sumowania 64, sygnał elementarny $80 \mathrm{~Hz}$
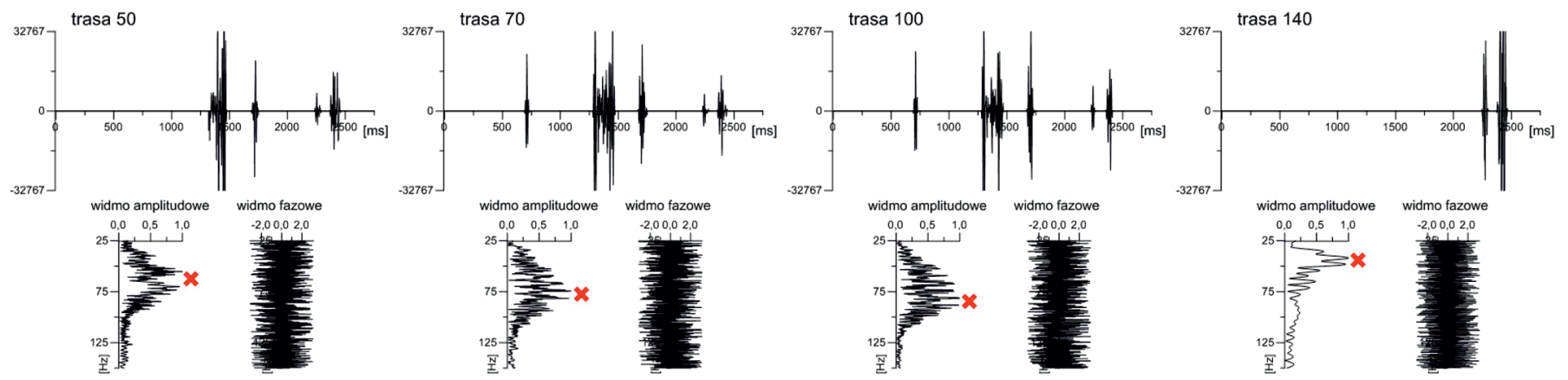

Rys. 10. Analiza zmian charakerystyki spektralnej tras wybranych wzdłuż profilu, sumowanych z krotnością 06, 12, 48, 64, przy założonej częstotliwości $80 \mathrm{~Hz}$

Kształt widma amplitudowego (domena spektralna) nieznacznie zależy w prezentowanym przypadku od krotności sumowania, niemniej jest bardziej zróżnicowany niż odpowiadający mu zapis trasy sejsmicznej (domena czasowa).

Porównując wyniki uzyskane dla dwóch różnych częstotliwości dominujących sygnału elementarnego, wykorzystane w tworzeniu modelu konwolucyjnego dla obiektu SK_W1, zauważa się wyraźnie większą wrażliwość sekcji sejsmicznej o wysokiej częstotliwości na zastosowaną w procesie sumowania krotność. Potwierdza to wcześniejszą obserwację, że modyfikacja spektralna i zwiększenie zakresu widma zespolonego powinny być aplikowane na rekordach pojedynczych. Powyższe znajduje również odzwierciedlenie w wartościach rozdzielczości czasowej i głębokościowej obserwowanej dla konkretnych horyzontów.

Określenie rozdzielczości umożliwionych drogą zmiany charakterystyki spektralnej przedstawiono na rysun- kach 11 i 12, na przykładzie analizy pakietów cechsztyńskiego i stropu syluru po wprowadzeniu poprawki NMO zarejestrowanych na sekcjach czasowych IL140 oraz XL260 w interwale około $1280 \div 1450 \mathrm{~ms}$, jak też z refleksem rejestrowanym na czasie około $1700 \mathrm{~ms}$ generowanym na stropie horyzontu Ludlow (rysunek 11). Wyniki rozdzielczości czasowej i głębokościowej przy średniej prędkości propagacji $\mathrm{w}$ interwale $=5000 \mathrm{~m} / \mathrm{s}$ na rekordach pojedynczych po wprowadzeniu poprawki dynamicznej przedstawiono w tablicach 2 i 3.

Uzyskana rozdzielczość maleje z głębokością (lub z czasem propagacji), a więc cienkowarstwowa formacja sylurska (zgodnie z informacją wynikającą z obliczeń na modelu teoretycznym) nie będzie mogła być odtworzona z zadowalającą dokładnością (dla częstotliwości mniejszej niż $40 \mathrm{~Hz}$ ).

Na rysunku 12 przedstawiono zależność rozdzielczości od krotności sumowania. 
a)

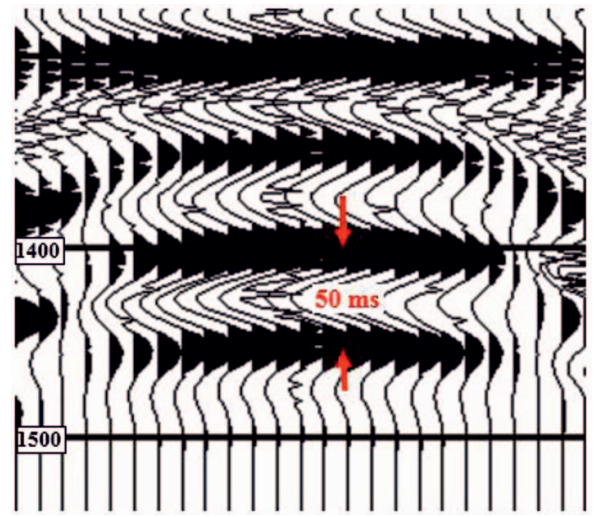

b)

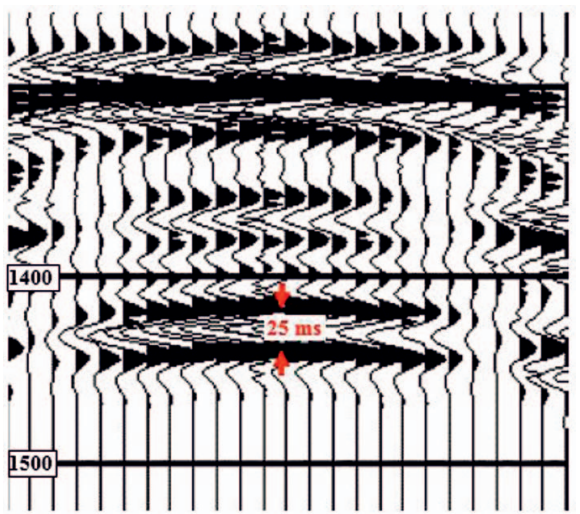

c)

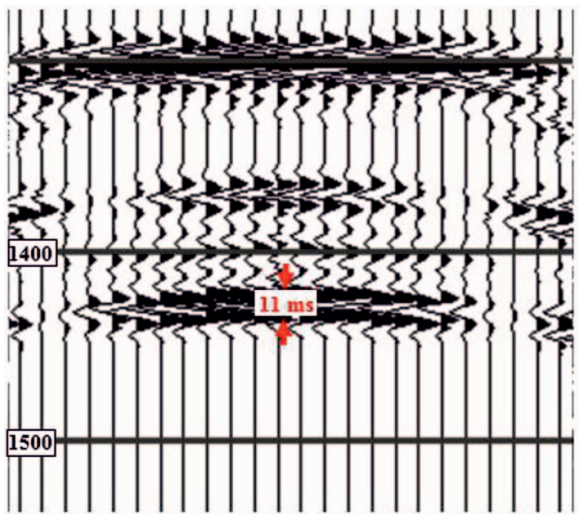

Rys. 11. Ocena rozdzielczości teoretycznego pola falowego w zależności od częstotliwości aplikowanego w modelowaniu (rys. 6b) sygnału elementarnego; $20 \mathrm{~Hz}$ (a), $40 \mathrm{~Hz}$ (b), $80 \mathrm{~Hz}$ (c)

a)

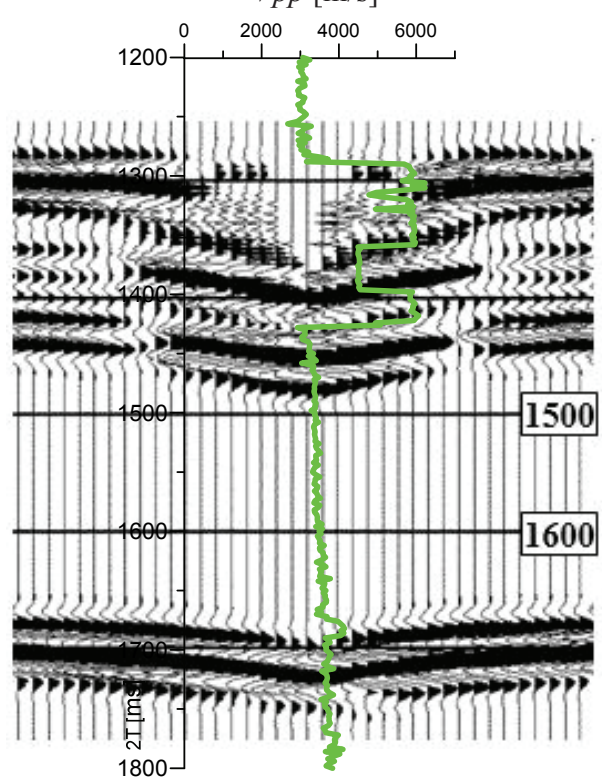

d)

$\operatorname{Vpp}[\mathrm{m} / \mathrm{s}]$

$1200 \stackrel{0}{2} \stackrel{2000}{1}, \frac{4000, \frac{6000}{1}}{1}$

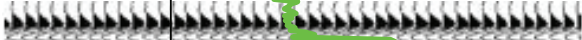
7)

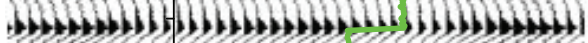
S1: 1 in in stossh

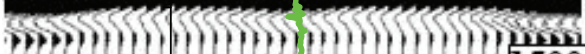

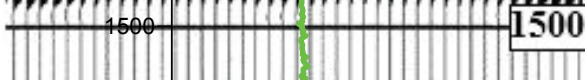
\begin{tabular}{|r|l|l|l|}
1600 & & 1600 \\
\hline
\end{tabular}

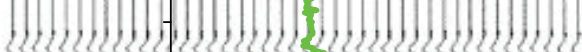

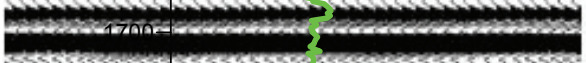

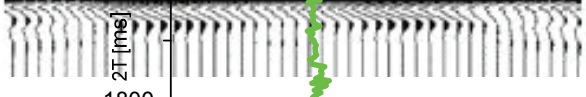
1800 b)

$V p p[\mathrm{~m} / \mathrm{s}]$

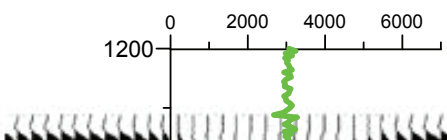

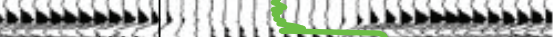

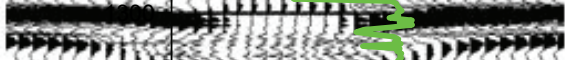
(5) MPR2 SELC2 (T)

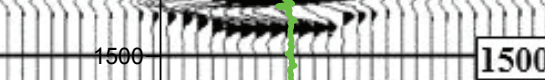
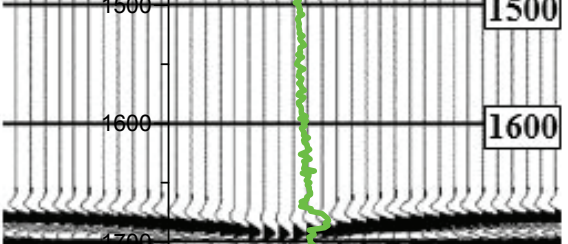

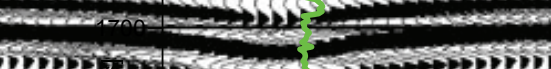

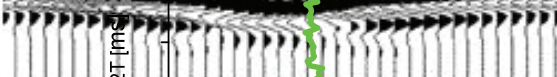
1800

e)

$\operatorname{Vpp}[\mathrm{m} / \mathrm{s}]$

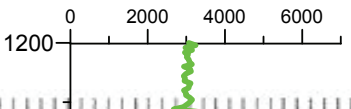

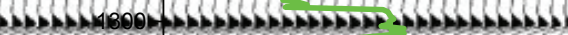

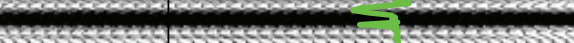

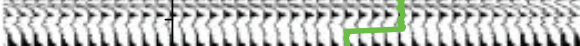

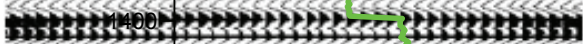

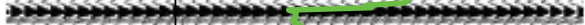

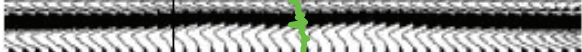
(P)

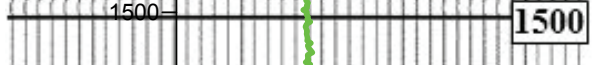

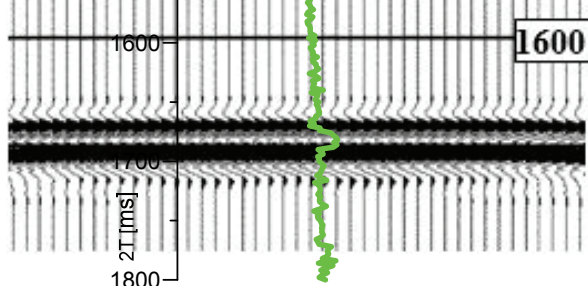

c) $V p p[\mathrm{~m} / \mathrm{s}]$ $1200 \stackrel{0 \quad 2000}{\perp} \frac{4000, \frac{6000}{\perp}}{1}$

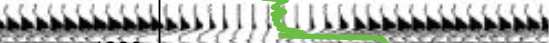

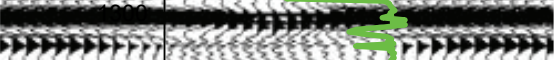

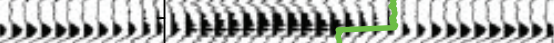

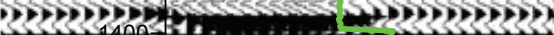
ZL2L21400-14

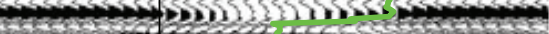

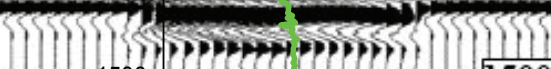

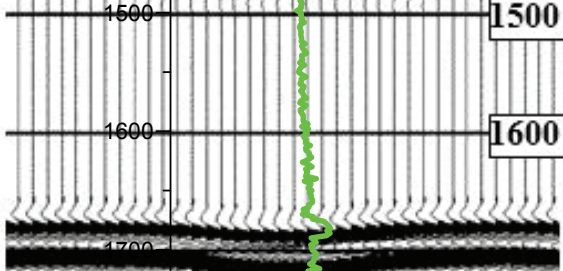

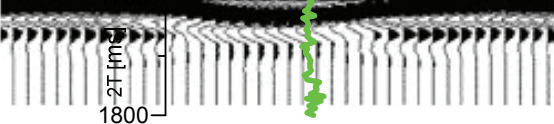

Rys. 12. Porównanie teoretycznego obrazu falowego, modelowanego dla obiektu SK W1 z zastosowaniem sygnału elementarnego syntetycznego o częstotliwości $40 \mathrm{~Hz}$, najlepiej odpowiadającego rzeczywistemu obrazowi sejsmicznemu w zależności od wykorzystywanej krotności sumowania (06-a, 12-b, 24-c, 48-d, 64-e) 
Tablica 2. Zależność rozdzielczości czasowej i głębokościowej rejestracji sejsmicznej w zależności od częstotliwości dominującej sygnału elementarnego

\begin{tabular}{|c|c|c|}
\hline $\begin{array}{c}\text { Częstotliwość } \\
{[\mathrm{Hz}]}\end{array}$ & $\begin{array}{c}\text { Rozdzielczość } \\
\text { czasowa }[\mathrm{ms}]\end{array}$ & $\begin{array}{c}\text { Rozdzielczość } \\
\text { głębokościowa }[\mathrm{m}]\end{array}$ \\
\hline 20 & 50 & 250 \\
\hline 40 & 25 & 125 \\
\hline 80 & 11 & 52 \\
\hline
\end{tabular}

Jak wynika z porównania tablic 2 i 3, osiągnięcie rozdzielczości $52 \mathrm{~m}$ realizowane na hodografie pojedynczym wymaga częstotliwości dominującej $80 \mathrm{~Hz}$; analogiczną rozdzielczość można uzyskać dla częstotliwości $40 \mathrm{~Hz}$ poprzez sumowanie z krotnością 24.

Jak już wspomniano, powyższe wyniki otrzymano na danych modelowych. Weryfikacja praktyczna przedstawiona będzie w kolejnej części niniejszego cyklu, na który składają
Tablica 3. Zależność rozdzielczości czasowej i głębokościowej od krotności sumowania dla założonej częstotliwości dominującej pola falowego równego $40 \mathrm{~Hz}$

\begin{tabular}{|c|c|c|c|}
\hline Krotność & $\begin{array}{c}\text { Częstotliwość } \\
{[\mathrm{Hz}]}\end{array}$ & $\begin{array}{c}\text { Rozdzielczość } \\
\text { czasowa }[\mathrm{ms}]\end{array}$ & $\begin{array}{c}\text { Rozdzielczość } \\
\text { głębokościowa [m] }\end{array}$ \\
\hline 06 & 40 & 25 & 125 \\
\hline 12 & 40 & 15 & 70 \\
\hline 24 & 40 & 11 & 52 \\
\hline 48 & 40 & 8 & 40 \\
\hline 64 & 40 & 6 & 30 \\
\hline
\end{tabular}

się aktualnie następujące artykuły: Dobór optymalnej rozdzielczości sekcji sejsmicznej na drodze analizy i modyfikacji charakterystyk spektralnych danych sejsmiki powierzchniowej i otworowej [5] oraz Nowe aspekty modyfikacji spektralnej pola sejsmicznego fal podtużnych z wykorzystaniem pomiarów prędkości fal poprzecznych w otworze [8].

\section{Podsumowanie}

Przytoczone zależności i fakty analizowane były na danych syntetycznych, a więc w sytuacji, kiedy wiele zakłóceń nie występuje, gdyż po prostu nie zostały uwzględnione w zapisie modelu, aby nie utrudniać selekcji elementów ważnych i mniej ważnych. Zwrócenie uwagi na pewnie szczegóły występujące w procedurach powszechnie i od wielu lat używanych w przetwarzaniu i interpretacji danych sejsmicznych [5], kolejny już raz ukazuje jak wiele jest problemów do przeanalizowania i to niekoniecznie na poziomie rozwiązywania skomplikowanych układów równań, ale podczas aplikowania prostych procedur z często nieuświadamianą wagą chronologii działań. Na poparcie powyższych uwag przytoczyć można większość artykułów, które ukazały się w „The Leading Edge” w lutym 2017 roku, którego specjalny dział (Special Section) poświęcony jest niepewności tworzenia modeli prędkości (Velocity Model Uncertainty). Autorzy zwracają uwagę na fakt, iż im bardziej skomplikowany jest analizowany obiekt geologiczny, tym większa jest rola badań i obliczeń na modelach [np. 8,9].

Prosimy cytować jako: Nafta-Gaz 2017, nr 12, s. 907-917, DOI: 10.18668/NG.2017.12.01

Artykuł nadesłano do Redakcji 12.04.2017 r. Zatwierdzono do druku 12.09.2017 r.

\section{Literatura}

[1] Goodway B., Ronen S.: Introduction to this special section: Offshore and onshore broadband seismology. The Leading Edge 2013, vol. 32, nr 11, s. 1354-1355.

[2] Jędrzejowska-Tyczkowska H.: Dobór optymalnej rozdzielczości sekcji sejsmicznej na drodze analizy i modyfikacji charakterystyk spektralnych danych sejsmiki powierzchniowej i otworowej. Nafta-Gaz 2017, nr 8, s. 531-550, DOI: 10.18668/ NG.2017.08.01.

[3] Jędrzejowska-Tyczkowska H.: Nowe aspekty modyfikacji spektralnej pola sejsmicznego fal podlużnych z wykorzystaniem pomiarów prędkości fal poprzecznych w otworze. Nafta-Gaz 2017, nr 11, s. 811-834, DOI: 10.18668/NG.2017.11.01.

[4] Jędrzejowska-Tyczkowska H.: Odtworzenie pożądanej rozdzielczości danych sejsmicznych $w$ aspekcie realizowanych zadań geologicznych. Prace Naukowe INiG 2012, nr 182, s. 57-63.

[5] Jędrzejowska-Tyczkowska H.: Renesans roli akwizycji w metodzie sejsmicznej w świetle poszukiwań niekonwencjonalnych złóż węglowodorów. Nafta-Gaz 2011, nr 11, s. 777-792.

[6] Jędrzejowska-Tyczkowska H.: The Impact of Phase Characteristics on Seismic Data Resolution. Second EAGE/SBGf Workshop 2014, 4-5 November, Copacabana, Rio de Janeiro, Brazil.
[7] Mann J.: Broadband seismic imaging improves subsurface mapping of Santos basin pre-salt reservoirs. World Oil, September 2013, s. 33-38.

[8] O’Brien G.S., Igoe M., Doherty I., Mahob P., Mecklenburgh R.: Offshore imaging with complex overburden: Understanding gather complexity and resulting attribute accuracy through synthetics. The Leading Edge 2017, vol. 36, nr 2, s. 159-165.

[9] Uieda L.: Step-by-step NMO correction. The Leading Edge 2017, vol. 36, nr 2, s. 179-180.

[10] Wiley M.L.: Structural and Stratigraphic Controls on Morrow Sandstone Reservoir Distribution from 3-D Seismic Data, Postle Field. Texas County 2009, Oklahoma.

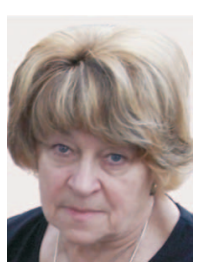

Prof. nzw. dr hab. inż. Halina JĘDRZEJOWSKATYCZKOWSKA

Instytut Nafty i Gazu - Państwowy Instytut Badawczy ul. Lubicz 25 A

31-503 Kraków

E-mail: tyczkowska@inig.pl 